\title{
Judicial Intervention in child and family at risk: Systematic analysis of case-files
}

Raquel Matos, Catarina Ribeiro, Cláudio Reis, Ana Almeida

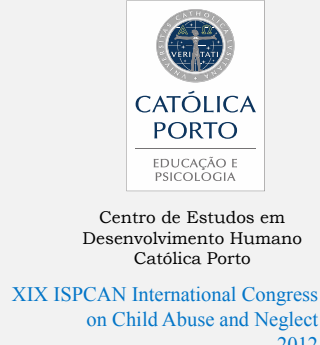

\section{Abstract}

Court intervention with children presents a set of characteristics that often result in difficulties and dilemmas for judges and other interveners, but also for the children themselves and their families. Emerging from an interface of pycheris and law process of judicial intervention including the interveners, their life contexts and the problems that led to judicie intervention, specifically in child abuse cases. Therefore in this research cases involving children, youth and their families with no specific scope of judicial action were analyzed using an exhaustive sample of two Portuguese family and youth courts. The methodology is mostly quantitative with a systematic analysis of 1465 cases pertaining to the year 2011 in both courts. In order to further expand the data on life contexts of both children and their families, qualitative sample of the cases was collected and analyzed, specifically in child abuse cases. Results have allowed the construction of an integrated model for continuous and systematic collection and analysis of information on these case-files, a basis from which to cany out specific stu sys to accompany these case fil

\section{Methodology}

Aims

To characterize families and children implicated in judicial situations on Child and Family Courts To understand the type of information collected in the early stages of judicial intervention

To uncover possible situations and dynamics of child endangerment.

Samples

Three samples were created using data from two Portuguese child and family courts during the period of 201 -Sample 1: 1465 forms filled while petitioning judicial intervention;

Procedures

Data was collected through the analysis of the case files, using an analysis grid. This procedure was followed by a statistical analysis using the SPSS software which wielded the following results.

Keywords: Judicial intervention; children and family law; child abuse; psychology and justice.

Results
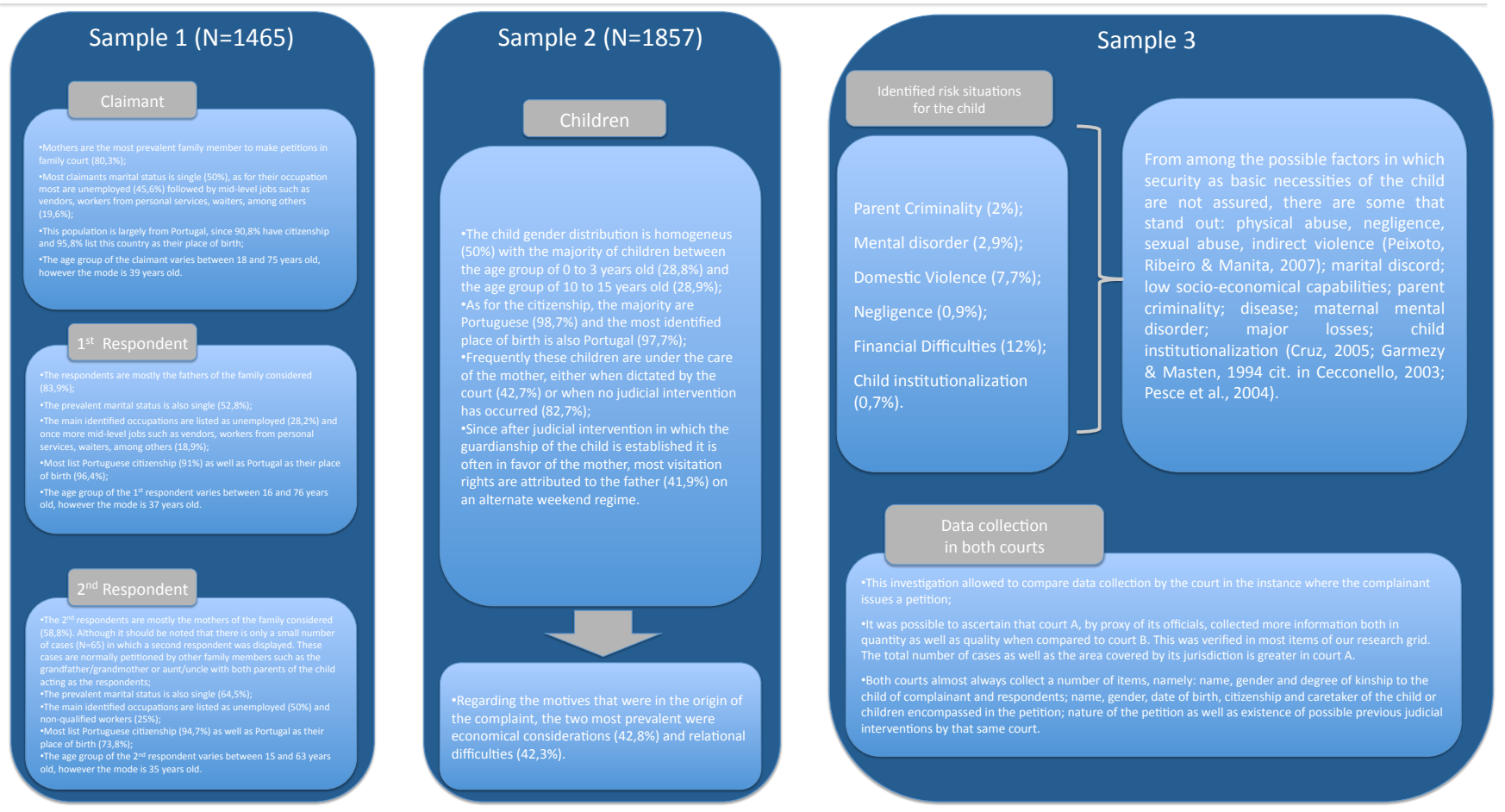

\section{Conclusions}

-The instauration of cases pertaining to child and family court are primarily requested by the mothers of the family in question;

wide ranging from 15 to 76 years. The most predominant marital status identified was single:

- Pertaining to the occupation, there is an elevated number of unemployed and the major occupation type is mid-level occupations and unskilled.

-As for the children, there is also a preponderance of Portuguese citizenship and place of birth. In single parent families where there was no judicial intervention the primary caretaker is the mother. In situations where there was judicial intervention and a child guardian was

established it is also primarily the mother;

-The most prevalent judicial intervention is the Regulation of Parental Responsibility in which certain aspects are established, namely alimony, child visiting rights, primary caretaker, among others. The second most prevalent judicial intervention has to do with failure to

-Most cases list as the catalyst for judicial intervention situations such as the severance of relationship/divorce, being unable and/or prevented from having contact with the child, and in a great number hindrance pertaining to child support/alimony.

Bibliography

•Cruz, O. (2005). Parentalidade. Coimbra: Quarteto.; Cecconllo, A. M. (2003). Resiliência e vulnerabilidade em familia em situação de risco. Tese de Doutoramento Publicada. Universidade Federal do Rio Grande do Sul.; Peixoto, C, E. Ribeiro, C. \& Manita, C. (2007). Avaliação psicológica forense das capacidades parentais. Revista da SPTM, 11, 142-156. 